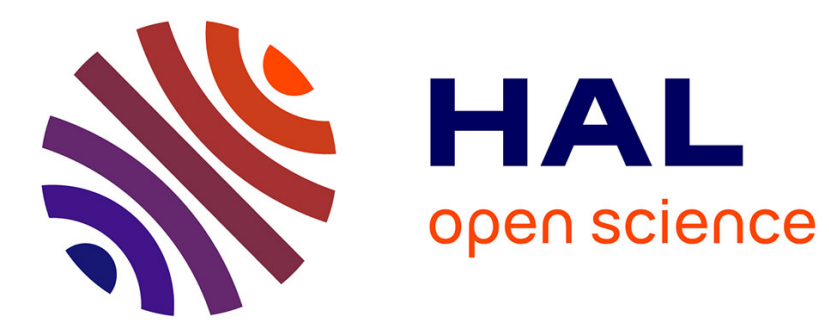

\title{
Who are Industry Specialist Auditors?
}

Like Jiang, Anne Jeny-Cazavan, Sophie Audousset-Coulier

\section{To cite this version:}

Like Jiang, Anne Jeny-Cazavan, Sophie Audousset-Coulier. Who are Industry Specialist Auditors?. Comptabilités et innovation, May 2012, Grenoble, France. pp.cd-rom. hal-00691057

\section{HAL Id: hal-00691057 https://hal.science/hal-00691057}

Submitted on 25 Apr 2012

HAL is a multi-disciplinary open access archive for the deposit and dissemination of scientific research documents, whether they are published or not. The documents may come from teaching and research institutions in France or abroad, or from public or private research centers.
L'archive ouverte pluridisciplinaire HAL, est destinée au dépôt et à la diffusion de documents scientifiques de niveau recherche, publiés ou non, émanant des établissements d'enseignement et de recherche français ou étrangers, des laboratoires publics ou privés. 


\title{
Who are Industry Specialist Auditors?
}

\author{
Like JIANG*, Anne JENY-CAZAVAN* and Sophie AUDOUSSET-COULIER** \\ * ESSEC Business School, ** John Molson School of Business, Concordia University
}

Résumé :L'objectif de cette recherche est d'analyser les effets de l'utilisation de définitions et de mesures multiples du concept de spécialisation sectorielle des auditeurs dans la recherche empirique en audit. Les auditeurs spécialistes d'un secteur industriel sont supposés produire un audit de meilleure qualité ce qui a entraîné le développement de mesures de la spécialisation sectorielle. Notre analyse démontre que l'utilisation de différentes définitions et mesures conduit à des classements non homogènes. Ainsi, selon la méthode utilisée, un même cabinet d'audit pourra être qualifié de « spécialiste » ou non d'un secteur industriel donné. Nous montrons également que l'absence de cohérence de ces définitions et mesures remet en question la significativité et la magnitude des résultats obtenus lorsqu'une mesure de spécialisation sectorielle des auditeurs est utilisée comme déterminant des honoraires d'audit, par exemple. Ce résultat a des implications méthodologiques pour les recherches empiriques en audit qui utilisent des mesures de spécialisation sectorielle des auditeurs.

Mots clés :Spécialisation sectorielle des auditeurs, honoraires d'audit

\section{Corresponding Author}

Anne JENY-CAZAVAN

Accounting department

ESSEC Business School

Ave Bernard Hirsch, B.P. 50105

95021 Cergy-Pontoise Cedex, FRANCE

e-mail: cazavan@essec.edu

\begin{abstract}
The purpose of this paper is to analyze the effects of using several definitions and several measurements of auditor industry specialization in the empirical audit research. Industry specialist auditors are supposed to be able to provide better quality audits therefore, auditor industry specialization measures have been developed and used in the empirical audit research. In a first step, we empirically test whether different definitions of auditor industry specialist result in consistent designations of audit firms as specialists of a given industry and find that inconsistent industry specialist definitions lead to inconsistent designation of audit firms as industry specialists. In a second step, we test and demonstrate that these different auditor industry designations lead to inconsistent results in terms of magnitude and significance regarding the fee premium paid toauditor industry specialists. Such evidence raises an issue of whether the findings in prior studies are subject to measurement errors of audit industry specialists
\end{abstract}

Keywords : Auditorindustryspecialists, audit fees 


\section{Introduction}

Audit firms characteristics and their influence on audit quality and audit pricing is a major interest for accounting researchers. Besides the dichotomy between Big firms and Non-Big firms, the main source of variation that has been tested is the variation in industry expertise (Francis, 2011). Despite the fact the auditor industryspecialization has been tested several times from different perspectives in the literature, the results can be seen as mixed (Francis, 2011). We argue that the mixed results can partially be attributable to the diversified approaches used to measure and to designate auditor industry specialists. In this paper, we empirically test this conjecture. We compare different measurements of auditor industry specializationin order to investigate if they produce different auditor industry specialist designations, and to test whether the different designations, if they exist, result in diversifiedimpactsofauditor industry specialization when this variable is used in audit quality and audit pricing empirical research models.

Who are industry specialistauditors? A survey of the websites of Big 4 audit firms showsthat all Big 4 auditors promote themselves asindustry specialists in almost all and every industry. However, in academic research, auditor industryspecializationis analyzed through the composition of the auditor'sclienteles because auditors who devote resources to develop special industry knowledge will tend to have larger market sharesand will be able to split the knowledge-developing costs and achieve economy of scales.Gramling and Stone (2001) demonstrate that in industryk, market shares of auditor firm ${ }_{\mathrm{i}}$ is measured as the total audit fees earned by auditor firm ${ }_{\mathrm{i}}$ in industry $\mathrm{k}$ deflated by the total audit fees generated by all the clients in the industry k. Because until recently, the information of audit fees wasnot publicly available, researchers used a variety of proxies to calculate auditor industry market shares. Those proxies are based on client firms'size (assets or sales revenues), or on the number of clients that an auditor has in one industry. Besides the different calculations of auditor industry market shares, the criteria applied to assign auditor industry specialists are diversified as well due to different definitions of auditor industry specialists. For instance, some researchers define auditor industry specialists as the one that possess the largest market share in a given industry (relative measure) whereas others define specialists as the ones that possess a market share in a given industrythat exceedscertain cutofflevels (absolute measure). The diversity of proxies used to measure auditor market shares and the inconsistent criteria adopted to assign auditor industry specialists render the empirical results hard to interpret. Since the audit fees are now publicly disclosed for listed firms, it raisesthe issue of whether the empirical results still hold when auditors' market shares are calculated withaudit fees instead of with proxies of audit fees. Our research attempts to shed light on this issue and adopts a two step methodology. We have first conducted an analysis of the different methods used in the literature to measure industry specialization and we have found seven different measurements of the auditors' industry market shares and two criterions to designate industry specialists (based on 
relative market shares or on absolute market shares). We have then used these fourteen different industry specialization measures to investigate if they produce different industry specialist assignments..In a second step, we have used alternatively the industry specialization assignments produced by the fourteen measurement methods in an audit fees determinants model to further test whether the different auditor industry specialist designations have differentiated impacts on audit pricing. We havecomparedthe significance and the magnitude of the coefficients of the auditor industry specialist variable in our audit fee determinants model.

Our results show that with the same assignment criterion, different proxies used to calculate industry market shares result in different designations of auditor industry specialists. Moreover, our regression results show that not all dummy variables of auditor industry specialist are significant. Finally, coefficients comparisons illustrate that there exist significant differences between some pairs of coefficients, meaning that the magnitude of effect that different auditor industry specialist designations have on audit fees are significantly different. Our results can be one explanation of the mixed empirical results that try to test the effect of auditor industry expertise. The paper contributes to the literature by empirically showing that when different proxies are used to measure market shares, even with the same assignment criterion, the designations of auditor industry specialist vary significantly. Furthermore, the measurement discrepancies can be large enough to influence the statistical results when auditor industry specialist is tested as an independent variable that influence audit pricing.

The remainder of the paper is organized as follows. Literature review and hypotheses development are in section 2, followed by data description in section 3 . Section 4 provides detailed information about the research design and the empirical results are stated in section 5. Section 6 concludes the paper.

\section{Literature Review and Hypotheses Development}

\subsection{Audit quality and auditor industry specialization: prior evidence}

Auditor industry specialization is a major topic in auditing literature. The importance of industry specialized auditors is attributable to the research findings that auditor industry expertise is associated with better auditor performance and higher audit quality. For better auditor performance, researchers argue that industry specialized auditors produce more accurate and efficient audit. For instance, Solomon and Shields (1999) use an experiment and show that industry specialist auditors have a greater quantity of and more accurate knowledge of financial statement non-error factors for their industries of specialization relative to other industries. Low (2004) examines the effects of industry specialization on auditors' risk assessment and audit-planning decisions and finds that industry knowledge improves audit risk assessment and influences the perceived quality of audit-planning decisions. 
The research of the association betweenauditor industry specialization and audit quality is extensive. One stream of literature argues that auditor industry expertise will help constrain earnings management thereby increasing earnings quality.For example, Balsam et al. (2003)find that clients of industry specialist auditors have lower DCA and higher ERC ${ }^{1}$ than clients of non-specialist auditors, suggesting that auditor industry specialization improves earnings quality.Similarly, Krishnan (2003) also supports the argument by showing that earnings management proxied by client's level of absolute discretionary accruals is lower for clients audited by industry specialist.

Another stream of research takes a more broad view and tests whether auditor industry specialization increases the overall client disclosure quality and reduces the frequency of fraudulent financial reporting.Dunn and Mayhew (2004) document a positive relation between industry specialist audit firms and analysts' rankings of disclosure quality in unregulated industries. However, the relation does not exist in regulated industries. Carcello and Nagy (2004) reports a negative relationship between auditor industry specialization and financial fraud, but such negative relationship is weaker for larger clients because larger clients have more bargaining power and it ismore difficult for an auditor to possess industry expertise due to clients' complex operating in more than one industry. Overall prior empirical evidence shows that auditor industry specialization seems to be positively associated with different proxies of audit quality. Nevertheless, as Francis (2011) claimed "more research is needed to understand the source of industry expertise and its relation to global, country-level, and office-specific operations of large accounting firms".

Furthermore, some researchers focus their analysis on the effect that industry specialized auditors have on audit pricing. For example, Casterella et al. (2004) find that a fee premium exists for industry specialist auditors in the small client segment but audit fees decrease as a company becomes increasingly larger relative to the auditor's industry clientele, suggesting that larger clients have stronger bargaining power and this power offset the fee premium effect.Huang et al. (2007) test whether the results of Casterella et al. (2004) will still hold for the post-SOX periods and they find that in the post-SOX period (i.e., 2003 and 2004) the negative association between audit fees and client size extends to both small and large client segments.

In addition, some studies adopt another strategy to test the moderatingeffect that industry specialized auditors may have on already tested relationships. Gul et al. (2009) investigate whether auditor industry specialization influences the observed positive relationship between auditor tenure and earnings quality and find that the relationship is significantly weakened for firms that are audited by industry specialists.Lim and Tan (2008)examines whether the relation between the provision of non-audit services and the impairment of audit quality is conditional on auditor specialization. Contrast to widely help claim that non-audit service impairs audit quality, the author find that there is no significant relationship between non-audit service and decreased audit quality. Rather, the results show that for clients who are audited by industry specialists, an increased level of non-audit service is positively associated with the incidence of issuing going-concern opinions. Knechel et al. (2007)hypothesizethat if capital market

${ }^{1}$ DCA refers to discretionary accruals and ERC refers to earnings response coefficient. 
considers industry specialized auditors as suppliers of high audit quality services, it will value the high quality and will react to auditor switches. Their findings suggest that within Big 4 auditors, market react positively when firms switch from a non-specialist Big 4 auditor to a specialist Big 4 auditor, consistent with market perceiving industry specialization to be valuable after controlling for the effects of brand name. However, the effect of switches between non-Big 4 and Big 4 specialists are somewhat ambiguous.

\subsection{A lack of consistent definition and measurement of Auditor}

\section{Industry Specialization}

Although studies on auditor industry specialization are extensive, definition and designation of industryspecialized auditor are not clearly agreed upon by researchers. Regarding the definition, most research follows Palmrose (1986) who defines auditor industry specialists to include the largest supplier in each industry, as well as the second and third largest suppliers in the industry in which readily observable differences existed between the second and the third or between the third and the remaining suppliers. This definition basically takes the within-industry market share approach in which an auditor is considered to be industry specialists if it possesses a significant part of the market shares in that industry. The rationale for defining specialists on the basis of market share is that auditors who devote resources to develop special industry knowledge to become industry specialists will tend to have as large market shares as possible in order to split the knowledge-developing costs and achieve economy of scales.An alternative definition of auditor industry specialization emphasizes auditor firm individually and focuses on the relative distribution of audit services across the various industries for each audit firms. This within-firm portfolio share approach defines audit firms as specialists in those industries which consist of the largest portfolio shares for the audit firms. The rationale for this kind of designation is that industries with largest portfolio shares generate most revenues for the audit firms because presumably they have devoted the most resources into developing industry-specific knowledge even if they do not have leading market shares.Additionally, Neal and Riley (2004) develop a weighted-market share approach ${ }^{2}$ which combines the two previous approaches. Finally, some researchers adopt a straightforward self-proclaimed approach in which audit firms are considered industry specialists if they promote their particular industry specialization at their websites. Table 1 summarizes the approaches that previous empirical papers applied to measure industry specialized auditors. The table shows that the within industry market share approach dominates the literature.

\footnotetext{
${ }^{2}$ In this approach, a firm's market share is weighted by its portfolio share. For example, if a firm has a market share of $30 \%$ in industry $\mathrm{k}$ and industry $\mathrm{k}$ accounts for a portfolio share of $2 \%$, the weighted market share is $0.6 \%$. A firm is designated as industry specialist if its weighted market share exceeds the cutoff ratio which is calculated as:$$
\left(\frac{1}{N_{\text {firms }}} * 1.2\right) *\left(\frac{1}{N_{\text {industries }}}\right)
$$ 


\section{[Insert Table 1 here]}

Regardless of the consensus that larger market shares indicate better industry knowledge, the calculation of auditor market share is not unified in the literature. Gramling and Stone (2001) identified that the market shares of auditor firm i in the industry $\mathrm{k}^{3}$ is measured as the total audit fees earned by auditor firm $\mathrm{i}$ in industry $\mathrm{k}$ deflated by the total audit fees generated by all the clients in the industry k. However, becauseuntilrecently information onaudit fees was not publicly available, researchers often replaced audit fees with (i) client size which is proxied by client assets and sales revenues and (ii) the number of clients.In addition to the variety of proxies utilized to measure market shares, the assignment criteria for auditor industry specialist arealso complicated. Industry specialist auditors are selected according to a relative level of market shares or to an absolute level of market shares. For relative level, specialists are selected as the ones having thelargest market shares, or the first two largest market shares, or the first three largestmarket shares. For absolute level, specialists are selected when their market shares are $20 \%$ greater than those if the audit firms were to split the industry evenly among them. Some researchers adopt a more rigid approach and identify specialist as the one with largest market share which should also be at least $10 \%$ higher than the second one (i.e., the dominance).

\subsection{Hypotheses development}

The diversity of proxies used to measure auditor market shares and the inconsistent criteria adopted to assign auditor industry specialist render the empirical results hard to interpret. Now that audit fees are publicly disclosed, it raises the question of whether the empirical results still hold when market shares are calculated withaudit fees based measures instead ofwith other proxies of audit fees. Our research attempts to shed light on this issue by comparing the designations of auditor industry specialist across various industry specialist measurements.

We hypothesize that different measurement proxies produce inconsistent resultsof auditor industry specialist designations

H1: The use of different proxies to measure auditor industry market shares producesinconsistent auditor industry specialist assignments.

Moreover, if the assignment results are inconsistent, the auditor industry specialists resultingfrom different measurements will producedissimilar impactswhen auditor industry specialization is used as an independent variable in empirical models. To empirically test this conjecture, we use an audit fee model and make the hypothesisthat auditor industry specialists resultingfrom different measurements will have

\footnotetext{
${ }^{3}$ Most existing research uses two-, three-, or four-digit SIC code to assign companies to different industries.
} 
differentimpacts on audit fees.

$\mathrm{H} 2$ : The use of different measurements proxies to identify auditor industry specialists producesinconsistent impacts on audit fees.

\section{Data}

This study selects all Canadian companies with financial data available in Compustat for the fiscal year 2007. We restrict the sample to industrial firms and exclude banks and financial institutions (all firms with SIC codes 6000-6999). From this list of non-financial companies we have downloaded the Annual information Forms (AIF) available on SEDAR to collect manually ${ }^{4}$ audit related data reported in their AIF (audit fees and auditor names). Our final sample for the auditor industry specialization measurements and audit fees estimation model has 824 observations for the year 2007.

The 824 companies are assigned to 20 industries based on theirfour-digit SIC. Table 2 presents composition of the sample by industries. It shows that the largest industry is Metal and Coal Mining which has 211 observations (26\% of the total sample), followed by the industry ofOil and Gas Extraction which has 151 observations (18\% of the total sample).

\section{[Insert Table 2 here]}

There are six main audit firms in the Canadian audit market. Those six audit firms are the BIG4 audit firms, namely Deloitte \&Touche (DTT), Ernst \& Young (EY), KPMG, and PricewaterhouseCoopers (PWC), and two other international audit networks which are Grant Thorntorn (GT) and BDO Dunwoody (BDO). Besides these six audit firms, other small audit firms also provides services in the Canadian market. Table 3 shows the distribution of sample companies' auditors. Table 3 Panel A separates the sample by BIG4 auditors versus NonBIG4 auditors and shows that the majority of sample companies are audited by BIG4 auditors (83\%). Table 3 Panel B provides information of the number of sample companies that are audited by each audit firms. Because each small audit firm only takes very small proportion of market shares and are not comparable to the six major players, we aggregate other small audit firms as one category (Other). It shows that KMPG has the largest market share, followed by PWC, DTT and EY.

[Insert Table 3 here]

\footnotetext{
${ }^{4}$ Detailed audit fee data (with a split between legal audit fees, and non-audit fees) are not available in databases for Canadian companies. Compustat provides "total fees" (= audit fees + non-audit fees) for a list of Canadian companies, and Audit Analytics only includes Canadian firms listed on a U.S. stock market.
} 


\section{Research Design}

\subsection{Calculation of Auditor Industry Market Shares}

Our research focuses on within industry market share approach because this approachis the most often used measurement in the literature. Table 1 shows that all previous empirical paper applied this approach, even if they sometimes complement their analyses with other approaches. We think that the variability offered by the different proxies and assignments in the market share approach is sufficient to test whether different auditor industry specialization measures lead to consistent or inconsistent results. Using only market share approach enables us also to keep the measurement concept constant. According to Gramling and Stone (2001), within industry market shares of auditor firm ${ }_{\mathrm{i}}$ in the industry ${ }_{\mathrm{k}}$ is measured as the total audit fees earned by auditor firm ${ }_{\mathrm{i}}$ in industry $\mathrm{k}_{\mathrm{k}}$ deflated by the total audit fees generated by all the clients in the industry k. For the purpose of comparison, we select audit fee based measures (audit fees and total fees) as well asthe other proxies used in the literature to measure auditor industry market shares. In a survey of prior studies, we find that client size, i.e., assets and sales revenues, are the most often used proxies. Moreover, the number of clients is also frequently employed as another proxy. In addition, because non-audit services may have an impact on auditor's development of industry expertise, we also use total fees (i.e., audit fees plus non-audit fees) as another measure. Following Gramling and Stone (2001), the formula used to calculate auditor industry market shares is:

$$
M S_{i k}=\frac{\sum_{j=1}^{J_{i k}} X_{i j k}}{\sum_{i=1}^{I_{k}} \sum_{j=1}^{J_{i k}} X_{i j k}}
$$

Where:

$\mathrm{MS}_{\mathrm{ik}}=$ market share of audit firm I for industry $\mathrm{k}$

$\mathrm{X}_{\mathrm{ijk}}=$ audit fees, total fees (audit fees + non-audit fees), total assets, total sales, number of clients of firm $\mathrm{j}$ audited by audit firm $\mathrm{i}$ in industry $\mathrm{k}$, respectively

$\mathrm{i}=$ auditor

$\mathrm{k}=$ industry

$\mathrm{j}=$ client

With this calculating formula and five different values of variable $\mathrm{X}$, we obtain five different market shares for each auditor in each industry.

Gramling and Stone (2001) also suggest that the relationship of audit fees and client size may not be linear. They show that based on Danos and Eichenseher (1982),audit fees tend to vary linearly with the square root of client size. Some recent papers actually take this proposition into account and use square root of client size instead of client size itself. Accordingly, we also includeanother formula for calculating 
market shares.

$$
M S_{i k}=\frac{\sum_{j=1}^{J_{i k}} \sqrt{X_{i j k}}}{\sum_{i=1}^{I_{k}} \sum_{j=1}^{J_{i k}} \sqrt{X_{i j k}}}
$$

Where:

$\mathrm{X}_{\mathrm{ik}}=$ total assets or total sales of audit firm $\mathrm{i}$ in industry $\mathrm{k}$

The other variables are the same as those in equation (1)

With this calculating formula and the two values of variable $\mathrm{X}$, we obtain two other market shares for each auditor in each industry. In sum, we use audit fees, total fees, total assets, sales revenues, number of clients, square root of assets and square root of salesto calculate auditor industry market shares, resulting in seven different market shares calculations for each auditor in each industry.

\subsection{Criteria for assigning auditor industry specialist}

After the calculation of market shares, we adopt two criteria to assign auditor industry specialists. According to Palmrose (1986), auditor industry specialists include the largest supplier in each industry, as well as the second and third largest suppliers in the industry in which readily observable differences existed between the second and the third or between the third and the remaining suppliers.In line with this definition, the first criterion (Criterion 1) for assigning industry specialist is based on the largest market shares. That is, auditor with the largest market shares is selected as the industry specialist in that industry. This assignment approach results in one auditor industry specialist per industry. The second assignment criterion (Criterion 2) is to assign industry specialists as the ones which serve market shares $20 \%$ greater than if the audit firms were to split the industry evenly among them, i.e., market share larger than 1 deflated by the number of audit firms in the industry. This assignment approach may result in several auditor industry specialists in one industry. In our study, we take the six major audit firms as the major players while aggregating other small audit firms as one category. In this sense, none of the small audit firms is considered a single player in the market. As a result, for criterion 2 the cutoff ratio is calculated as $(1 / 6)^{*}(1+20 \%)$ which equals to $20 \%$. In short, assignment criterion 2 can be expressed as industry market shares larger than $20 \%$.

\subsection{Statistical model to test hypotheses}

In order to test hypothesis $\mathrm{H} 1$, we first calculate the seven market shares of each auditor in each industry. Then we apply assignment criterion 1 and criterion 2 respectively to designate auditor industry specialists for each industry. This results in seven designations for each industry in each criterion.We compare descriptively 
whether with the same assignment criterion, the resulting auditor industry specialists are the same for the different measurement proxies in each industry.

To test hypothesis $\mathrm{H} 2$, we run the analysis at the firm level. We create dummy variables $\mathrm{ISpec}_{\mathrm{ij}}$ to indicate whether a firm is audited by industry specialist, where ${ }_{i}$ refers to the assignment criterion and ${ }_{j}$ refers to the variables used to calculate auditor industry marketshares.For assignment criterion 1, since there are seven designations based on different market share calculation, we create seven dummy variables named from ISpec11 to ISpec17. Those dummy variables equals to 1 if a firm is audited by the industry specialized auditor and 0 otherwise. For assignment criterion 2, we do the same time and create 7 dummy variables named from ISpec21 to ISpec27.

To test whether different auditor industry specialist designations produce similar statistical results on the relationship between audit industry specialization and audit fees, we regress audit fees on different ISpec $\mathrm{c}_{\mathrm{ij}}$ and compare whether the coefficients of different ISpecij are the same. We adopt a within assignment criterion approach. That is, for each assignment criterion, we do the regression seven times using seven different ISpecijeach time. The first analysis is to see whether all ISpecij are significant in the regression. Second, we combine the regression estimates in pairs as seemly unrelated estimates and analyzewhether the coefficients of ISpecij are the same. The regression model in our test is:

$$
\begin{aligned}
& \text { LnAUDFEE }=a_{0}+a_{1} L n A S S E T S+a_{2} B I G 4+a_{3} I N V R E C+a_{4} R O A+a_{5} L O S S \\
& +a_{6} M I N I N G+a_{7} C R O S S L I S T+a_{8} w L E V+a_{9} I S S U E+a_{10} I S p e c i j+\varepsilon \\
& \mathrm{i}=\text { criterion } \\
& \mathrm{j}=\text { variable used to calculate auditor industry market shares }
\end{aligned}
$$

All the variables are defined in the appendix A

Audit fees (LnAUDFEE) correspond to the fees (log) paid by companies to their auditors for the audit of the year-end financial statements.

We control for client size (LnASSETS), because the demand for audit services is likely to increase with firm size, leading to a positive association between firm size and audit fees. Size is measured as the logarithm of total assets. Audit fees are likely to increase with the complexity of clients' business operations. Following past literature, we include the variable INVREC (measured by the proportion of inventories and accounts receivable in the total assets) to proxy for client complexity. All the coefficients of the aforementioned variables are expected to be positive (Simunic 1980; Choi et al. 2010). Prior research also showed a positive association between clients' riskiness and audit fees (Simunic and Stein 1996) and a negative association with client's profitability. Then we include LOSS (if the firm has experienced losses during the current or previous period), LEV (leverage), and ROA (return on assets) to proxy for a client's risk characteristics.

In order to capture the effect of audit quality differentiation on audit fees, we include BIG4. A positive coefficient of BIG4 means the existence of fee premiums for high-quality auditors belonging to a BIG4 international auditing network. To control 
for audit demand effects, we include ISSUE (if the firm has issued new long term debt or common equity representing more than $5 \%$ of the total assets). Firms involved in equity and debt offerings (Reynolds et al. 2004) are in a greater need of audit services. Considering the specific characteristics of our Canadian sample, we control for the impacts of the cross-listing on a US stock market (CROSSLIST).as previous literature (Seetharaman et al. 2002, Choi et al. 2010) has shown that audit fees increase when the litigation risk is higher. Finally, we include one industry indicator variable (MINING) to control for industry differences.

\section{ResearchResults}

\subsection{Descriptive statistics}

Table 4 presents the descriptive statistics of the variables, showing that our sample covers a wide range of companies. The mean assets of sample companies is 1070 thousands (\$CAN), with standard deviation of 3681 thousands. The mean audit fees are488 thousands, with standard deviation of 1149 thousands. On average, sales revenues generated by sample companies in 2007 were 699 thousands. Proportion of inventory and receivables relative to total assetsranges from $2 \%$ to $87 \%$, and the mean ratio is $17 \%$. However, the mean of LOSS shows that about $53 \%$ of sample companies reported loss in 2007, consistent with the negative mean ROA. In addition, $23 \%$ of the sample firmscrosslist in US exchange and more than half of them issued new debt or equity that is more than $5 \%$ of the lag total assets in 2007.

\section{[Insert Table 4 here]}

Table 5 is the correlation matrix of the variables used in our statistical model. All ISpecij are significantly correlated to each other, but their correlations with other firm-specific variables are somehow different. For instance, all ISpecij significantly correlate to LnAUDFEEexcept for ISpec15 and ISpec25, indicating that the number of clients may not be appropriate in terms of proxy of audit fees. In addition, ISpec 25 does not significantly correlate to BIG4, whereas other ISpecij do. In contrast, only ISpec25 significantly correlates to ROA, LOSS, and ISSUE, whereas others do not. This result indicates that ISpec 25 are quite different from other ISpecij. Furthermore, even within the same assignment criterion, there are discrepancies among different ISpecij. For example, for assignment criterion 1, only ISpec11 significantly correlates to INVREC and MINING. For assignment criterion 2, ISpec24 and ISpec25 correlate CROSSLIST significantly, whereas others do not. In sum, the correlation matrix shows that designations of auditor industry specialists resulted from different market share measurements and specialist assignmentcriteria are different in terms of theircorrelations with other firm characteristics.

[Insert Table 5here] 


\subsection{Results of auditor industry specialists designation}

Table 6 summarizes designation results of auditor industryspecialist. Panel A presents the results for criterion 1 and Panel B presents the results for criterion 2. In both criteria, industry specialized auditors are Big 4 audit firms. Nevertheless, as shown by Panel A, in criterion 1 the seven measurements of industry market shares do not yield exactly the same industryspecialists assignment results. For instance, for Industry 4 (i.e., industry of Food and kindred Products) DTT is assigned as the industry specialized auditor by method 1, 2 and 7, whereas KPMG is assigned as specialist by method 3 and 6. Moreover, in the same industry, method 4 designates EY as the industry specialized auditor but in method 5 the auditor industry specialist becomes PWC. The results descriptively show that even with the same assignment criterion, using different proxies to calculate industry market shares yields inconsistent industry specialized auditors. Similarly, in Panel B, the assignment results of criterion 2 are not consistent as well. For instance, in Industry 1 (i.e., industry of Metal and Coal Mining), PWC and DTT are selected as industry specialized auditors by method 1, 2 and 6 . However, in method 3, 4 and 7 three auditors, namely PWC, DTT and KPMG, are assigned as industry specialists. More differently, in method 5, only PWC is designated as auditor industry specialist.In sum, the two tables descriptively show that within the same assignment criterion, different measurements of auditor industry market shares result in different designations of auditor industryspecialists, supporting hypothesis 1.

[Insert Table 6here]

\subsection{Results of comparing the effects of different auditor industry}

\section{specialists designation on audit pricing}

To test whether different ISpecij of criterion 1 have the same effect on audit fees, we run the regression of our audit fees pricing model (3), seven times by adding different ISpecij of criterion 1(i.e., ISpec11 to ISpec17) each time. The regression results are shown in Table 7. We name each regression model according to the ISpec that is included in the model. For example, if ISpec11 is included, the regression model is named MODEL11. As shown in the table, R-squares of all seven regressions are around 0.72 which is satisfactorily high. F-tests are significant for all models. However, not all ISpecij are significant. The coefficient of ISpec12 is significant at 0.05 level with t-statistic of 1.99 ( $\mathrm{p}=0.046)$, while coefficients of ISpec13 and ISpec14 are significant at 0.1 level with t-statistic of $1.72(\mathrm{p}=0.086)$ and $1.83(\mathrm{p}=0.068)$ respectively. ISpecij in other models are not significant. The results support hypothesis 2 , suggesting that when the assignment criterion is the largest market shares, the resulting auditor industry specialists from different industry market shares measurements have dissimilar impact on audit fees in terms of significance.

[Insert Table 7 here] 
To further test hypothesis 2 , we redo the test usingcriterion 2 . That is, we run the regression again seven times by including ISpec21 to ISpec27 each time. The regression results are shown in Table 8. It shows that only the coefficients of ISpec 21 and ISpec23 are significant at 0.1 level with t-statistic of $1.71(\mathrm{p}=0.088)$ and 1.92 $(p=0.056)$ respectively. However, coefficients of ISpecij are not significant in other models. This result again support hypothesis 2 .

\section{[Insert Table 8 here]}

Correlation matrix shows that some ISpecij are significantly correlated to other control variables, casting doubt that our estimates may be biased because of multicollinearity. We test the level of multicollinearity in each model and the results are reported in Appendix B. The mean VIFs of each model arelow, suggesting that there no severe multicollinearity problem in our tests.

In the next step, weexplore the difference in effectmagnitude ofISpecij. That is, we test whether the coefficients of different ISpecij from the same assignment criterion are statistically the same. To operationalize the comparison,regression estimates of each model in the same criterion are combined as seemly unrelated estimates in pairs and the coefficients of ISpecijare tested in pairs.Comparison results for models in criterion 1 and criterion 2 are shown in Table 9, panels A and B, respectively. In Table 9, panel A, coefficients of ISpec11 to ISpec17 are compared in pairs. The table shows that some pairs of ISpec coefficients are significantly different. For instance, chi-square statistic of comparison between coefficients of ISpec12 and ISpec15 is 6.39 ( $\mathrm{p}=0.0115)$, demonstrating that these two coefficients are significantly different at 5\% level. Similarly, difference between coefficients of ISpec13 and ISpec16 is also significantly at 5\% level. Moreover, differences between coefficients of ISpec13 and ISpec16, and between coefficients of ISpec14 and ISpec15 are significantlydifferent at 1\% level. In addition, coefficients of ISpec14 and ISpec16, coefficients of ISpec14 and ISpec17, and coefficients of ISpec15 and ISpec17 are significantly different in pairs at 10\% level.

\section{[Insert Table 9here]}

Table 9, panel Bsummarizes the coefficient comparison results for ISpec in criterion 2 (i.e., compare ISpec21 to ISpec27 in pairs). It shows that coefficient of ISpec25 is significantly different from coefficients of other ISpec. The difference is significant at $1 \%$ level between ISpec25 and ISpec21, between ISpec25 and 22, between ISpec25 and ISpec23, between ISpec25 and ISpec24, and between ISpec25 and ISpec26. The difference between the coefficients of ISpec25 and ISpec27 is significant at 5\% level. Additionally, coefficients of ISpec23 and ISpec27 are significantly different at $1 \%$ level.

In sum, the results show that the impact that different auditor industry specialist designations has on audit fees are not the same. Applying the same regression, we find that with assignment criterion as largest market shares, ISpecij measured from sales, audit fees and total fees are significant.

However, with assignment criterion as market share larger than: 


$$
\frac{1}{N_{\text {firms }}} * 1.2 \text { (i.e., in our research, the ratio is }(1 / 6) * 1.2=0.2 \text { ), }
$$

ISpecij measured from assets and audit fees in are significant at $10 \%$ level. Furthermore, when combing the regression estimates as seemly unrelated estimates to test the difference in effect magnitude of different ISpecij, some coefficient pairs are statistically significant from each other.

\section{Conclusion}

In this paper, we empirically test whether different measurements of auditor industry specialist results in the same designations of industry specialized auditors for Canadian listed companies. Adopting a within industry market shares approach, we find that with the same industry specialist assignment criterion, different proxies and formulas used to calculate auditor industry market shares produce different industry specialized auditors. Moreover, the firm-level regression of audit fees on different auditor industry designations shows that auditor industry specialist does not always have significant effect on audit fees. When regression estimates are combined as seemly unrelated estimates and the coefficients of ISpecij are compared in pairs within the same assignment criterion, the difference between some ISpecij coefficients pairs become statisticallysignificant. Our results provide empirical evidence that the effect significance and effect magnitude of different auditor industry specialistmeasurements on audit fees can be different due to the diversity of market shares calculations. Such evidence, in turn, raises an issue of whether the findings in prior studies are subject to measurement errors of audit industry specialists. 


\section{References}

Balsam, S., Krishnan, J., Yang, J.S., 2003.Auditor industry specialization and earnings quality. Auditing: A Journal of Practice and Theory 22 (2), 71-97.

Carcello, J.V., Nagy, A.L., 2004. Client size, auditor specialization, and fraudulent financial reporting. Managerial Auditing Journal 19, 651-668.

Casterella, J.R., Francis, J.R., Lewis, B. L., Walker P.L., 2004.Auditor industryspecialization, client bargaining power, and audit pricing. Auditing, A Journal of Practice and Theory. 23 (1), 123-140.

Choi, J.-H., Kim, J.-B.andZang, Y. (2010). Do abnormally high audit fees impair audit quality? Auditing: A Journal of Practice and Theory 29(2), 115-140.

Danos, P. and Eichenseher, J.V. (1982). Audit industry dynamic: Factors affecting changes in client-industry market shares, Journal of Accounting Research, Vol. 20, pp. 604-616.

Dunn, K.A., Mayhew, B.W., 2004. Audit firm industryspecialization and client disclosure quality. Review of Accounting Studies 9, 35-58.

Francis, J.R., 2011. A Framework for Understanding and Research Audit Quality. Auditing: A Journal of Practice and Theory 30 (2), 125-152.

Gramling, A.A., Stone, D.N., 2001. Audit Firm Industry Expertise: A review and Synthesis of the Archival Literature. Journal of Accounting Literature 20, 1-29

Gul, F.A., Fung, S.Y-K., Jaggi, Bikki., 2009. Earnings quality: Some evidence on the role of auditor tenure and auditors' industry expertise. Journal of Accounting and Economics 47, 265-287.

Huang Hua-Wei, LiuLi-Lin, Raghunandan, K., and Dasaratha, R.V., 2007. Auditor industry specialization, client bargaining power, and audit fees: Further evidence. Auditing: A Journal of Practice and Theory 26 (1), 147-158

Knechel, R.W., Naiker, V., Pacheco, G., 2007. Does auditor industryspecialization matter? Evidence from larket reaction to auditor switches.Auditing: A Journal of Practice and Theory 2(1), 19-45.

Krishnan, G.V., 2003. Does Big 6 auditor industry expertise constrain earnings management? Accounting Horizons (Supplement), 1-16.

Low, K.Y., 2004. The effects of industry specialization on audit risk assessment and audit-planning decisions. The accounting Review 79, 201-219 
Neal, T.L., Riley, R.R., 2004. Auditor industry specialist research design.Auditing: A Journal of Practice and Theory 23(2), 169-177.

Palmrose, Z-V, 1986. Audit fees and auditor size: Further evidence. Journal of accountingResearch 24 (1), 97-110.

Reynolds, J. L., Deis, D. and Francis, J. R. (2004). Professional service fees and auditor objectivity.Auditing: A Journal of Practice and Theory, 23(1), 29-52.

Seetharaman, A., Gul, F. A. and Lynn, S. G. (2002). Litigation risk and audit fees: evidence from U.K. firms cross-listed on U.S. markets. Journal of Accounting and Economics, 33(1), 91-115.

Simunic, D. A. (1980).The Pricing of Audit Services: Theory and Evidence. Journal of Accounting Research, 18(1): 161-190.

Simunic, D. A. and Stein M. T. (1996). The impact of litigation risk on audit pricing: A review of the economics and evidence. Auditing: A Journal of Practice and Theory, 15 (supplement), 119-133.

Solomon, I., Shields, M. D., 1999. What does industry-specialist auditor know? Journal of Accounting Research 37 (1), 191-208. 
Table 1: Summary of measurements used by empirical papers

\begin{tabular}{|l|l|l|l|l|}
\hline Article & Market share & Portfolio share & Weighted market share & Self-proclaimed \\
\hline Palmrose (1986) & $\mathrm{X}$ & & & \\
\hline Hogan and Jeter (1999) & $\mathrm{X}$ & & & $\mathrm{x}$ \\
\hline Balsam et al. (2003) & $\mathrm{X}$ & & & \\
\hline Krishnan (2003) & $\mathrm{X}$ & $\mathrm{x}$ & & \\
\hline Dunn (2004) & $\mathrm{X}$ & & & \\
\hline Carcello and Nagy (2004) & $\mathrm{X}$ & & & \\
\hline Casterella et al. (2004) & $\mathrm{X}$ & & $\mathrm{x}$ & \\
\hline Cairney and Young (2006) & $\mathrm{X}$ & $\mathrm{X}$ & & \\
\hline Huang et al. (2007) & $\mathrm{X}$ & & & \\
\hline Kwon et al. (2007) & $\mathrm{X}$ & & & \\
\hline Knechel et al. (2007) & $\mathrm{X}$ & & & \\
\hline Lim (2008) & $\mathrm{X}$ & $\mathrm{X}$ & & \\
\hline Cahan et al. (2008) & $\mathrm{X}$ & & \\
\hline Gul et al. (2009) & & & & \\
\hline
\end{tabular}


Table 2: Sample Industries

\begin{tabular}{|l|l|l|l|}
\hline & Industry & \# of Firms & Proportion \\
\hline 1 & Metal and Coal Mining & 211 & $26 \%$ \\
\hline 2 & Oil and Gas extraction & 151 & $18 \%$ \\
\hline 3 & Nonmetallic Minerals & 15 & $2 \%$ \\
\hline 4 & Food and kindred products & 22 & $3 \%$ \\
\hline 5 & Wood products & 13 & $2 \%$ \\
\hline 6 & Paper products, printing and publishing & 17 & $2 \%$ \\
\hline 7 & Chemical products & 55 & $7 \%$ \\
\hline 8 & Rubber and misc. Plastic products & 10 & $1 \%$ \\
\hline 9 & Metal products & 15 & $2 \%$ \\
\hline 10 & Industrial equipment & 16 & $2 \%$ \\
\hline
\end{tabular}

\begin{tabular}{|l|l|l|l|}
\hline & Industry & \# of Firms & Proportion \\
\hline 11 & Electric and electronic equipment & 39 & $5 \%$ \\
\hline 12 & Transportation equipment & 15 & $2 \%$ \\
\hline 13 & Instruments and related products & 20 & $2 \%$ \\
\hline 14 & Transportation services & 25 & $3 \%$ \\
\hline 15 & Communication services & 17 & $2 \%$ \\
\hline 16 & Utilities & 36 & $4 \%$ \\
\hline 17 & Wholesale & 21 & $3 \%$ \\
\hline 18 & Retail & 36 & $4 \%$ \\
\hline 19 & Business services & 64 & $8 \%$ \\
\hline 20 & Other services & 26 & $3 \%$ \\
\hline & Total & 824 & $100 \%$ \\
\hline
\end{tabular}


Table 3: Sample Audit Firms

Panel A: BIG4 vs. Non-BIG4

\begin{tabular}{|l|l|l|}
\hline & \# of Obs. & Proportion \\
\hline BIG4 & 681 & $83 \%$ \\
\hline NonBIG4 & 143 & $17 \%$ \\
\hline
\end{tabular}

Panel B: Individual Audit Firms

\begin{tabular}{|l|l|l|}
\hline Audit Firm & \# of Obs. & Proportion \\
\hline Deloitte \&Touche & 143 & $17.4 \%$ \\
\hline Ernst \& Young & 131 & $16.0 \%$ \\
\hline KPMG & 209 & $25.3 \%$ \\
\hline PwC & 198 & $24.0 \%$ \\
\hline Grant Thorntorn & 28 & $3.4 \%$ \\
\hline BDO Dunwoody & 25 & $3.0 \%$ \\
\hline Other Small Firms & 90 & $10.9 \%$ \\
\hline
\end{tabular}


Table 4: Descriptive Statistics of Variables

\begin{tabular}{|c|c|c|c|c|c|c|c|c|}
\hline Variable & $\mathrm{N}$ & mean & sd & $\min$ & p25 & p50 & p75 & $\max$ \\
\hline AUDFEE & 824 & 487.6319 & 1149.271 & 10 & 85.2355 & 177.625 & 370.61 & 16200 \\
\hline LnAUDFEE & 824 & 5.301822 & 1.196639 & 2.302585 & 4.445414 & 5.179668 & 5.915139 & 9.692766 \\
\hline ASSETS & 824 & 1070.348 & 3681.337 & 1.815 & 41.7705 & 126.038 & 506.8155 & 46974 \\
\hline LnASSETS & 824 & 5.052315 & 1.844952 & 0.5960855 & 3.732181 & 4.83658 & 6.228145 & 10.75735 \\
\hline TOTALFEE & 824 & 699.0464 & 1540.485 & 14.684 & 140.579 & 287.25 & 602.465 & 20800 \\
\hline NETINC & 824 & 50.26852 & 286.9952 & -969.2 & -8.7685 & -0.632 & 15.2965 & 4057 \\
\hline SALES & 824 & 655.2688 & 2426.581 & 0 & 1.6525 & 49.2275 & 256.63 & 32815 \\
\hline BIG4 & 824 & 0.8264563 & 0.3789466 & 0 & 1 & 1 & 1 & 1 \\
\hline INVREC & 824 & 0.1679687 & 0.1862845 & 0 & 0.0243688 & 0.0881206 & 0.2648053 & 0.8734282 \\
\hline ROA & 824 & -0.0847158 & 0.3371057 & -2.903605 & -0.1160116 & -0.0082595 & 0.0572314 & 2.47734 \\
\hline LOSS & 824 & 0.526699 & 0.4995899 & 0 & 0 & 1 & 1 & 1 \\
\hline MINING & 824 & 0.256068 & 0.4367249 & 0 & 0 & 0 & 1 & 1 \\
\hline CROSSLIST & 824 & 0.2281553 & 0.4198981 & 0 & 0 & 0 & 0 & 1 \\
\hline wLEV & 824 & 0.372784 & 0.2529987 & 0.0092233 & 0.173249 & 0.3433774 & 0.5262196 & 1.302034 \\
\hline ISSUE & 824 & 0.5364078 & 0.4989756 & 0 & 0 & 1 & 1 & 1 \\
\hline
\end{tabular}


Table 5: Variable Correlations

\begin{tabular}{|c|c|c|c|c|c|c|c|c|c|c|}
\hline & LnAUDFEE & LnASSETS & BIG4 & INVREC & ROA & LOSS & MINING & CROSSLIST & wLEV & ISSUE \\
\hline LnAUDFEE & 1 & & & & & & & & & \\
\hline LnASSETS & $0.7609^{*}$ & 1 & & & & & & & & \\
\hline BIG4 & $0.3198^{*}$ & $0.3015^{*}$ & 1 & & & & & & & \\
\hline INVREC & $0.1849^{*}$ & $-0.0714^{*}$ & -0.0252 & 1 & & & & & & \\
\hline ROA & $0.1721 *$ & $0.3605^{*}$ & 0.0606 & $0.0706^{*}$ & 1 & & & & & \\
\hline LOSS & $-0.3499^{*}$ & $-0.4278^{*}$ & $-0.1648 *$ & $-0.1790^{*}$ & $-0.4903^{*}$ & 1 & & & & \\
\hline MINING & $-0.2777 *$ & $-0.1666^{*}$ & $-0.2010^{*}$ & $-0.3616^{*}$ & -0.0521 & $0.2721^{*}$ & 1 & & & \\
\hline CROSSLIST & $0.2735^{*}$ & $0.1276^{*}$ & -0.0258 & $-0.0875^{*}$ & $-0.1111^{*}$ & 0.0346 & $0.1316^{*}$ & 1 & & \\
\hline wLEV & $0.4171^{*}$ & $0.2255^{*}$ & $0.0724 *$ & $0.3645^{*}$ & $-0.1070^{*}$ & $-0.1354^{*}$ & $-0.3869^{*}$ & $0.0785^{*}$ & 1 & \\
\hline ISSUE & $-0.1681^{*}$ & 0.0001 & $-0.1176^{*}$ & $-0.2119^{*}$ & $0.1830^{*}$ & $-0.0770^{*}$ & $0.2332^{*}$ & 0.0125 & $-0.2571^{*}$ & 1 \\
\hline ISpec11 & $0.1433^{*}$ & $0.1624^{*}$ & $0.2680^{*}$ & $-0.0943^{*}$ & 0.0019 & -0.009 & $0.0908^{*}$ & 0.0271 & 0.0045 & -0.0092 \\
\hline ISpec12 & $0.1158^{*}$ & $0.1049^{*}$ & $0.2757^{*}$ & -0.0608 & 0.0311 & 0.0091 & 0.075 & -0.0194 & -0.0094 & -0.0246 \\
\hline ISpec13 & $0.1303^{*}$ & $0.1075^{*}$ & $0.3068^{*}$ & -0.0252 & 0.0435 & 0.0036 & 0.0163 & 0.0051 & -0.0035 & -0.0462 \\
\hline ISpec14 & $0.1300^{*}$ & $0.1086^{*}$ & $0.3007^{*}$ & -0.05 & 0.0395 & 0.0126 & 0.0272 & 0.0215 & -0.0079 & -0.0426 \\
\hline ISpec15 & 0.0482 & 0.0421 & $0.3173^{*}$ & 0.0146 & 0.0244 & 0.0279 & -0.0022 & -0.0118 & 0.0076 & -0.0427 \\
\hline ISpec16 & $0.1062 *$ & $0.1154^{*}$ & $0.3129^{*}$ & -0.058 & 0.02 & 0.0105 & 0.0054 & 0.02 & -0.0166 & -0.0237 \\
\hline ISpec17 & $0.1242^{*}$ & $0.1212^{*}$ & $0.3033^{*}$ & -0.0555 & 0.0164 & -0.0116 & 0.0225 & 0.0423 & -0.0038 & -0.0192 \\
\hline ISpec21 & $0.2320^{*}$ & $0.2255^{*}$ & $0.4905^{*}$ & -0.0674 & 0.0413 & -0.0572 & $-0.1041^{*}$ & -0.008 & 0.0643 & -0.0538 \\
\hline ISpec22 & $0.2331^{*}$ & $0.2261^{*}$ & $0.4549 *$ & -0.0319 & 0.0545 & -0.0555 & -0.0597 & 0.0155 & $0.0747^{*}$ & -0.0457 \\
\hline ISpec23 & $0.2270^{*}$ & $0.2313^{*}$ & $0.5139^{*}$ & $-0.1192 *$ & 0.044 & -0.0135 & $0.0698^{*}$ & 0.0598 & 0.0085 & -0.0108 \\
\hline ISpec24 & $0.2413^{*}$ & $0.2418^{*}$ & $0.5454 *$ & $-0.0889^{*}$ & 0.04 & -0.0266 & 0.0357 & $0.0693^{*}$ & 0.0353 & -0.0251 \\
\hline ISpec25 & -0.0055 & $0.1288^{*}$ & -0.0495 & $0.3805^{*}$ & $0.4281^{*}$ & $0.6055^{*}$ & $0.5436^{*}$ & $0.7076^{*}$ & $0.6301 *$ & $0.5604^{*}$ \\
\hline ISpec26 & $0.2451^{*}$ & $0.2353^{*}$ & $0.5126^{*}$ & -0.027 & 0.0515 & -0.0598 & $-0.1303^{*}$ & -0.0145 & $0.1144 *$ & -0.0425 \\
\hline ISpec27 & $0.2552^{*}$ & $0.2609^{*}$ & $0.5413 *$ & -0.0521 & 0.0548 & -0.0632 & 0.04 & 0.0674 & $0.0808^{*}$ & -0.0369 \\
\hline
\end{tabular}




\section{Table 5: Variable Correlations (continued)}

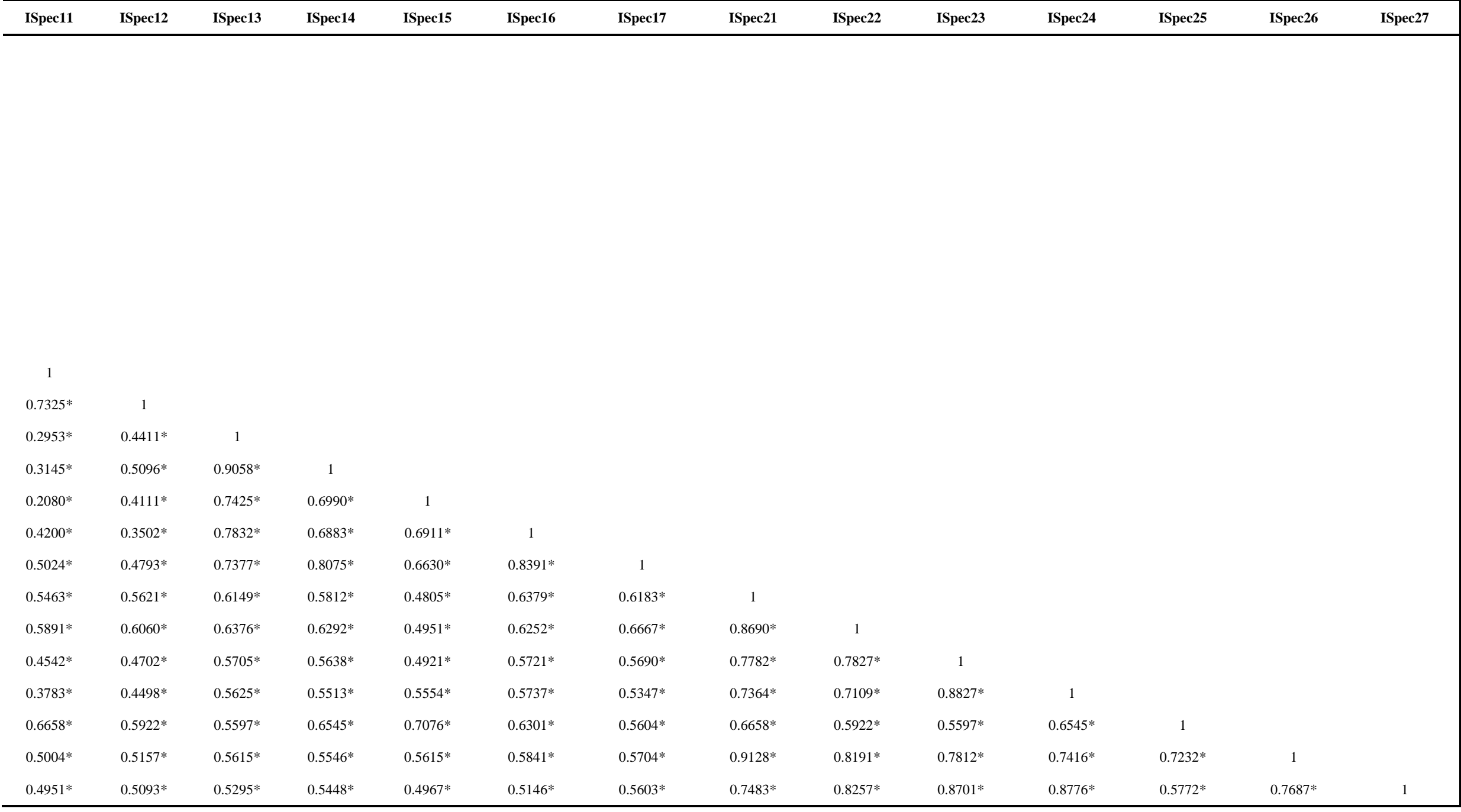


Table 6: Summary of Auditor Industry Specialists

Panel A: Assignment Criterion 1: Largest Market Share

\begin{tabular}{|c|c|c|c|c|c|c|c|}
\hline Industry & Method 1 & Method 2 & Method 3 & Method 4 & Method 5 & Method 6 & Method 7 \\
\hline 1 & PWC & PWC & PWC & PWC & PWC & PWC & PWC \\
\hline 2 & PWC & PWC & KPMG & KPMG & KPMG & KPMG & KPMG \\
\hline 3 & KPMG & KPMG & KPMG & KPMG & PWC & PWC & KPMG \\
\hline 4 & DTT & DTT & KPMG & EY & PWC & KPMG & DTT \\
\hline 5 & PWC & PWC & KPMG & KPMG & KPMG & KPMG & KPMG \\
\hline 6 & DTT & KPMG & DTT & KPMG & None & DTT & KPMG \\
\hline 7 & KPMG & EY & EY & EY & EY & KPMG & KPMG \\
\hline 8 & PWC & PWC & EY & EY & DTT & PWC & DTT \\
\hline 9 & KPMG & KPMG & KPMG & KPMG & KPMG & KPMG & KPMG \\
\hline 10 & EY & EY & EY & EY & EY & KPMG & EY \\
\hline 11 & EY & EY & KPMG & KPMG & KPMG & KPMG & KPMG \\
\hline 12 & EY & EY & EY & EY & DTT & EY & EY \\
\hline 13 & PWC & PWC & KPMG & KPMG & EY & KPMG & KPMG \\
\hline 14 & PWC & PWC & PWC & PWC & EY & PWC & PWC \\
\hline 15 & DTT & DTT & DTT & DTT & DTT & DTT & DTT \\
\hline 16 & PWC & PWC & KPMG & KPMG & PWC & PWC & PWC \\
\hline 17 & DTT & DTT & DTT & DTT & DTT & DTT & DTT \\
\hline 18 & KPMG & KPMG & DTT & KPMG & DTT & DTT & KPMG \\
\hline 19 & PWC & KPMG & KPMG & KPMG & KPMG & KPMG & KPMG \\
\hline 20 & $\mathrm{EY}$ & DTT & $\mathrm{EY}$ & EY & PWC & EY & $\mathrm{EY}$ \\
\hline
\end{tabular}

Variables used in each method:

Method 1: assets

Method 2: sales

Method 3: audit fees
Method 4: total fees

Method 5: Number of clients

Method 6: square root of asset

Method 7: square root of sales 
Panel B: Assignment Criterion 2: Market Share > 20\%

\begin{tabular}{|c|c|c|c|c|c|c|c|}
\hline Industry & Method 1 & Method 2 & Method 3 & Method 4 & Method 5 & Method 6 & Method 7 \\
\hline 1 & PWC, DTT & PWC, DTT & PWC, DTT, KPMG & PWC, DTT, KPMG & PWC & PWC, DTT & PWC, DTT, KPMG \\
\hline 2 & PWC, KPMG & PWC, KPMG & KPMG, PWC & KPMG, PWC & KPMG, PWC & KPMG, PWC & KPMG, PWC \\
\hline 3 & KPMG, PWC & KPMG & KPMG, PWC & KPMG, PWC & PWC & PWC, KPMG & KPMG \\
\hline 4 & DTT, KPMG & DTT & None & EY, KPMG, PWC & PWC, KPMG & None & DTT, PWC, EY \\
\hline 5 & PWC, KPMG & PWC, KPMG & KPMG, PWC & KPMG, PWC & KPMG, PWC & KPMG, PWC & KPMG, PWC \\
\hline 6 & DTT, KPMG & KPMG, DTT, PWC & DTT, KPMG, PWC & KPMG,DTT, PWC & None & DTT, KPMG & KPMG, DTT, PWC \\
\hline 7 & KPMG, EY & EY, KPMG & EY, KPMG & EY, KPMG & EY, KPMG & KPMG, EY & KPMG, EY \\
\hline 8 & PWC,DTT & PWC, KPMG, DTT & EY, DTT, KPMG & EY, DTT, PWC & DTT & PWC, DTT, KPMG & DTT, PWC, KPMG \\
\hline 9 & KPMG, EY & KPMG, EY & KPMG, EY & KPMG, EY & KPMG & KPMG, EY & KPMG, EY \\
\hline 10 & EY, KPMG & EY, KPMG, DTT & EY, KPMG, DTT & EY, KPMG, DTT & EY, KPMG, DTT & KPMG, EY & EY, KPMG, DTT \\
\hline 11 & EY, KPMG, PWC & EYKPMG & KPMG, PWC & KPMG, PWC & KPMG & KPMG, EY, PWC & KPMG, EY \\
\hline 12 & EY & EY & $\mathrm{EY}$ & EY & DTT, PWC & EY, DTT, PWC & EY, KPMG \\
\hline 13 & PWC, KPMG & PWC, KPMG & KPMG, PWC & KPMG, EY, PWC & EY & KPMG, PWC & KPMG, PWC \\
\hline 14 & PWC, KPMG & PWC, KPMG & PWC, EY & PWC, EY, KPMG & EY, KPMG, PWC & PWC, KPMG, EY & PWC, KPMG, EY \\
\hline 15 & DTT, KPMG & DTT, KPMG & DTT, KPMG & DTT, KPMG & DTT, KPMG & DTT, KPMG & DTT, KPMG \\
\hline 16 & PWC, KPMG, EY & PWC, KPMG & KPMG, PWC, EY & KPMG, PWC, EY & PWC, EY, KPMG & PWC,EY, KPMG & PWC, EY, KPMG \\
\hline 17 & DTT & DTT & DTT & DTT & DTT, KPMG & DTT & DTT \\
\hline 18 & KPMG, DTT & KPMG, DTT & DTT, KPMG & KPMG, DTT & DTT, PWC & DTT, KPMG & KPMG, DTT \\
\hline 19 & PWC, DTT, KPMG & KPMG, PWC & KPMG, PWC & KPMG & KPMG, DTT & KPMG, PWC, DTT & KPMG, PWC \\
\hline 20 & EY, DTT & DTT, EY & EY, DTT & EY, DTT, PWC & PWC, EY & EY, DTT, PWC & EY, DTT, PWC \\
\hline
\end{tabular}

Variables used in each method:

Method 1: assets

Method 2: sales

Method 3: audit fees
Method 4: total fees

Method 5: Number of clients

Method 6: square root of asset

Method 7: square root of sales 
Table 7: Regression Results of Criterion 1

\begin{tabular}{|c|c|c|c|c|c|c|c|c|c|c|c|c|c|c|}
\hline & MODEL 1 & & MODEL 1 & & MODEL & & MODEL 1 & & MODEL 1 & & MODEL1 & & MODEL 1 & \\
\hline \multirow[b]{2}{*}{ LnASSETS } & Coef. & $\mathrm{t}$ & Coef. & $\mathrm{t}$ & Coef. & $\mathrm{t}$ & Coef. & $\mathrm{t}$ & Coef. & $\mathrm{t}$ & Coef. & $\mathrm{t}$ & Coef. & $\mathrm{t}$ \\
\hline & 0.452 & $\begin{array}{c}29.58 \\
(0.000)\end{array}$ & 0.453 & $\begin{array}{c}29.79 \\
(0.000)\end{array}$ & 0.453 & $\begin{array}{c}29.82 \\
(0.000)\end{array}$ & 0.453 & $\begin{array}{c}29.82 \\
(0.000)\end{array}$ & 0.454 & $\begin{array}{c}29.81 \\
(0.000)\end{array}$ & 0.454 & $\begin{array}{c}29.79 \\
(0.000)\end{array}$ & 0.454 & $\begin{array}{c}29.79 \\
(0.000)\end{array}$ \\
\hline BIG4 & 0.282 & $\begin{array}{c}4.33 \\
(0.000)\end{array}$ & 0.263 & $\begin{array}{c}4.02 \\
(0.000)\end{array}$ & 0.265 & $\begin{array}{c}4.02 \\
(0.000)\end{array}$ & 0.263 & $\begin{array}{c}4.00 \\
(0.000)\end{array}$ & 0.316 & $\begin{array}{c}4.73 \\
(0.000)\end{array}$ & 0.293 & $\begin{array}{c}4.44 \\
(0.000)\end{array}$ & 0.284 & $\begin{array}{c}4.31 \\
(0.000)\end{array}$ \\
\hline INVREC & 1.161 & $\begin{array}{c}8.28 \\
(0.000)\end{array}$ & 1.159 & $\begin{array}{c}8.29 \\
(0.000)\end{array}$ & 1.153 & $\begin{array}{c}8.24 \\
(0.000)\end{array}$ & 1.159 & $\begin{array}{c}8.28 \\
(0.000)\end{array}$ & 1.163 & $\begin{array}{c}8.29 \\
(0.000)\end{array}$ & 1.158 & $\begin{array}{c}8.26 \\
(0.000)\end{array}$ & 1.158 & $\begin{array}{c}8.26 \\
(0.000)\end{array}$ \\
\hline $\mathrm{ROA}$ & -0.214 & $\begin{array}{c}-2.62 \\
(0.009)\end{array}$ & -0.221 & $\begin{array}{c}-2.71 \\
(0.007)\end{array}$ & -0.223 & $\begin{array}{c}-2.73 \\
(0.006)\end{array}$ & -0.224 & $\begin{array}{c}-2.74 \\
(0.006)\end{array}$ & -0.213 & $\begin{array}{c}-2.60 \\
(0.010)\end{array}$ & -0.217 & $\begin{array}{c}-2.65 \\
(0.008)\end{array}$ & -0.217 & $\begin{array}{c}-2.65 \\
(0.008)\end{array}$ \\
\hline LOSS & -0.043 & $\begin{array}{c}-0.77 \\
(0.439)\end{array}$ & -0.048 & $\begin{array}{c}-0.85 \\
(0.397)\end{array}$ & -0.049 & $\begin{array}{c}-0.86 \\
(0.388)\end{array}$ & -0.049 & $\begin{array}{c}-0.88 \\
(0.380)\end{array}$ & -0.039 & $\begin{array}{c}-0.68 \\
(0.494)\end{array}$ & -0.043 & $\begin{array}{c}-0.77 \\
(0.444)\end{array}$ & -0.044 & $\begin{array}{c}-0.78 \\
(0.438)\end{array}$ \\
\hline MINING & -0.099 & $\begin{array}{c}-1.62 \\
(0.105)\end{array}$ & -0.106 & $\begin{array}{c}-1.74 \\
(0.082)\end{array}$ & -0.098 & $\begin{array}{c}-1.62 \\
(0.106)\end{array}$ & -0.099 & $\begin{array}{c}-1.62 \\
(0.105)\end{array}$ & -0.088 & $\begin{array}{c}-1.45 \\
(0.148)\end{array}$ & -0.091 & $\begin{array}{c}-1.50 \\
(0.133)\end{array}$ & -0.094 & $\begin{array}{c}-1.54 \\
(0.123)\end{array}$ \\
\hline CROSSLIST & 0.545 & $\begin{array}{c}9.90 \\
(0.000)\end{array}$ & 0.549 & $\begin{array}{c}9.98 \\
(0.000)\end{array}$ & 0.544 & $\begin{array}{c}9.90 \\
(0.000)\end{array}$ & 0.543 & $\begin{array}{c}9.87 \\
(0.000)\end{array}$ & 0.545 & $\begin{array}{c}9.89 \\
(0.000)\end{array}$ & 0.544 & $\begin{array}{c}9.88 \\
(0.000)\end{array}$ & 0.543 & $\begin{array}{c}9.86 \\
(0.000)\end{array}$ \\
\hline wLEV & 0.622 & $\begin{array}{c}5.85 \\
(0.000)\end{array}$ & 0.620 & $\begin{array}{c}5.84 \\
(0.000)\end{array}$ & 0.625 & $\begin{array}{c}5.89 \\
(0.000)\end{array}$ & 0.624 & $\begin{array}{c}5.88 \\
(0.000)\end{array}$ & 0.625 & $\begin{array}{c}5.88 \\
(0.000)\end{array}$ & 0.625 & $\begin{array}{c}5.88 \\
(0.000)\end{array}$ & 0.625 & $\begin{array}{c}5.88 \\
(0.000)\end{array}$ \\
\hline ISSUE & -0.167 & $\begin{array}{c}-3.47 \\
(0.001)\end{array}$ & -0.166 & $\begin{array}{c}-3.44 \\
(0.001)\end{array}$ & -0.165 & $\begin{array}{c}-3.43 \\
(0.001)\end{array}$ & -0.165 & $\begin{array}{c}-3.43 \\
(0.001)\end{array}$ & -0.168 & $\begin{array}{c}-3.48 \\
(0.001)\end{array}$ & -0.167 & $\begin{array}{c}-3.48 \\
(0.001)\end{array}$ & -0.167 & $\begin{array}{c}-3.48 \\
(0.001)\end{array}$ \\
\hline ISpec & 0.055 & $\begin{array}{c}1.02 \\
(0.308)\end{array}$ & 0.105 & $\begin{array}{c}1.99 \\
(0.046)\end{array}$ & 0.087 & $\begin{array}{c}1.72 \\
(0.086)\end{array}$ & 0.093 & $\begin{array}{c}1.83 \\
(0.068)\end{array}$ & -0.040 & $\begin{array}{c}-0.79 \\
(0.432)\end{array}$ & 0.013 & $\begin{array}{c}0.26 \\
(0.794)\end{array}$ & 0.038 & $\begin{array}{c}0.75 \\
(0.451)\end{array}$ \\
\hline _cons & 2.338 & $\begin{array}{c}20.38 \\
(0.000)\end{array}$ & 2.341 & $\begin{array}{c}20.50 \\
(0.000)\end{array}$ & 2.336 & $\begin{array}{c}20.46 \\
(0.000)\end{array}$ & 2.336 & $\begin{array}{c}20.47 \\
(0.000)\end{array}$ & 2.323 & $\begin{array}{c}20.34 \\
(0.000)\end{array}$ & 2.328 & $\begin{array}{c}20.36 \\
(0.000)\end{array}$ & 2.331 & $\begin{array}{c}20.39 \\
(0.000)\end{array}$ \\
\hline
\end{tabular}


Table 7: Regression Results of Criterion 1 (continued)

\begin{tabular}{|c|c|c|c|c|c|c|c|}
\hline & MODEL 11 & MODEL 12 & MODEL 13 & MODEL 14 & MODEL 15 & MODEL16 \\
\hline Num of obs & 824 & 824 & 824 & 824 & 824 & 824 \\
F( 10, 813) & 209.55 & 210.60 & 210.23 & 210.37 & 209.40 & 209.20 \\
Prob> F & 0.0000 & 0.0000 & 0.0000 & 0.0000 & 0.0000 & 0.724 .38 \\
R-squared & 0.7205 & 0.7215 & 0.7211 & 0.7213 & 0.7203 & 0.0000 \\
Adj R-squared & 0.7170 & 0.7181 & 0.7177 & 0.7178 & 0.7169 & 0.7203 \\
\hline
\end{tabular}

p-value in parentheses

ISpec is calculated based on variables:

Model 11: Assets

Model 12: Sales

Model 13: Audit fees

Model 14: Total fees

Model 15: Number of clients

Model 16: Square root of assets

Model 17: Square root of sales 
Table 8: Regression Results of Criterion 2

\begin{tabular}{|c|c|c|c|c|c|c|c|c|c|c|c|c|c|c|}
\hline & MODEL2 & & MODEL 2 & & MODEL 2 & & MODEL 2 & & MODEL 2 & & MODEL 2 & & MODEL 2 & \\
\hline \multirow[b]{2}{*}{ LnASSETS } & Coef. & $\mathrm{t}$ & Coef. & $\mathrm{t}$ & Coef. & $\mathrm{t}$ & Coef. & $\mathrm{t}$ & Coef. & $\mathrm{t}$ & Coef. & $\mathrm{t}$ & Coef. & $\mathrm{t}$ \\
\hline & 0.452 & $\begin{array}{c}29.63 \\
(0.000)\end{array}$ & 0.452 & $\begin{array}{c}29.60 \\
(0.000)\end{array}$ & 0.451 & $\begin{array}{c}29.52 \\
(0.000)\end{array}$ & 0.452 & $\begin{array}{l}29.550 \\
(0.000)\end{array}$ & 0.454 & $\begin{array}{c}29.89 \\
(0.000)\end{array}$ & 0.452 & $\begin{array}{c}29.65 \\
(0.000)\end{array}$ & 0.453 & $\begin{array}{c}29.59 \\
(0.000)\end{array}$ \\
\hline BIG4 & 0.245 & $\begin{array}{c}3.48 \\
(0.001)\end{array}$ & 0.259 & $\begin{array}{c}3.74 \\
(0.000)\end{array}$ & 0.227 & $\begin{array}{c}3.12 \\
(0.002)\end{array}$ & 0.246 & $\begin{array}{c}3.300 \\
(0.001)\end{array}$ & 0.344 & $\begin{array}{c}4.98 \\
(0.000)\end{array}$ & 0.257 & $\begin{array}{c}3.59 \\
(0.000)\end{array}$ & 0.277 & $\begin{array}{c}3.72 \\
(0.000)\end{array}$ \\
\hline INVREC & 1.171 & $\begin{array}{c}8.36 \\
(0.000)\end{array}$ & 1.158 & $\begin{array}{c}8.27 \\
(0.000)\end{array}$ & 1.166 & $\begin{array}{c}8.33 \\
(0.000)\end{array}$ & 1.159 & $\begin{array}{c}8.280 \\
(0.000)\end{array}$ & 1.145 & $\begin{array}{c}8.17 \\
(0.000)\end{array}$ & 1.162 & $\begin{array}{c}8.30 \\
(0.000)\end{array}$ & 1.156 & $\begin{array}{c}8.25 \\
(0.000)\end{array}$ \\
\hline ROA & -0.219 & $\begin{array}{c}-2.68 \\
(0.008)\end{array}$ & -0.220 & $\begin{array}{c}-2.69 \\
(0.007)\end{array}$ & -0.221 & $\begin{array}{c}-2.71 \\
(0.007)\end{array}$ & -0.219 & $\begin{array}{l}-2.680 \\
(0.008)\end{array}$ & -0.212 & $\begin{array}{c}-2.60 \\
(0.009)\end{array}$ & -0.220 & $\begin{array}{c}-2.69 \\
(0.007)\end{array}$ & -0.217 & $\begin{array}{c}-2.66 \\
(0.008)\end{array}$ \\
\hline LOSS & -0.048 & $\begin{array}{c}-0.86 \\
(0.392)\end{array}$ & -0.047 & $\begin{array}{c}-0.84 \\
(0.403)\end{array}$ & -0.051 & $\begin{array}{c}-0.92 \\
(0.360)\end{array}$ & -0.049 & $\begin{array}{l}-0.860 \\
(0.389)\end{array}$ & -0.035 & $\begin{array}{c}-0.63 \\
(0.530)\end{array}$ & -0.048 & $\begin{array}{c}-0.86 \\
(0.393)\end{array}$ & -0.044 & $\begin{array}{c}-0.78 \\
(0 . .438)\end{array}$ \\
\hline MINING & -0.089 & $\begin{array}{c}-1.47 \\
(0.143)\end{array}$ & -0.094 & $\begin{array}{c}-1.55 \\
(0.121)\end{array}$ & -0.110 & $\begin{array}{c}-1.80 \\
(0.073)\end{array}$ & -0.103 & $\begin{array}{l}-1.680 \\
(0.094)\end{array}$ & -0.102 & $\begin{array}{c}-1.68 \\
(0.094)\end{array}$ & -0.089 & $\begin{array}{c}-1.47 \\
(0.142)\end{array}$ & -0.097 & $\begin{array}{c}-1.57 \\
(0.116)\end{array}$ \\
\hline CROSSLIST & 0.546 & $\begin{array}{c}9.93 \\
(0.000)\end{array}$ & 0.544 & $\begin{array}{c}9.89 \\
(0.000)\end{array}$ & 0.541 & $\begin{array}{c}9.83 \\
(0.000)\end{array}$ & 0.541 & $\begin{array}{c}9.810 \\
(0.000)\end{array}$ & 0.545 & $\begin{array}{c}9.92 \\
(0.000)\end{array}$ & 0.546 & $\begin{array}{c}9.92 \\
(0.000)\end{array}$ & 0.543 & $\begin{array}{c}9.85 \\
(0.000)\end{array}$ \\
\hline wLEV & 0.618 & $\begin{array}{c}5.82 \\
(0.000)\end{array}$ & 0.617 & $\begin{array}{c}5.81 \\
(0.000)\end{array}$ & 0.617 & $\begin{array}{c}5.81 \\
(0.000)\end{array}$ & 0.618 & $\begin{array}{c}5.810 \\
(0.000)\end{array}$ & 0.639 & $\begin{array}{c}6.00 \\
(0.000)\end{array}$ & 0.613 & $\begin{array}{c}5.75 \\
(0.000)\end{array}$ & 0.619 & $\begin{array}{c}5.80 \\
(0.000)\end{array}$ \\
\hline ISSUE & -0.168 & $\begin{array}{c}-3.49 \\
(0.001)\end{array}$ & -0.168 & $\begin{array}{c}-3.49 \\
(0.001)\end{array}$ & -0.169 & $\begin{array}{c}-3.52 \\
(0.000)\end{array}$ & -0.169 & $\begin{array}{l}-3.510 \\
(0.000)\end{array}$ & -0.164 & $\begin{array}{c}-3.41 \\
(0.001)\end{array}$ & -0.170 & $\begin{array}{c}-3.53 \\
(0.000)\end{array}$ & -0.168 & $\begin{array}{c}-3.48 \\
(0.001)\end{array}$ \\
\hline ISpec & 0.088 & $\begin{array}{c}1.71 \\
(0.088)\end{array}$ & 0.068 & $\begin{array}{c}1.34 \\
(0.179)\end{array}$ & 0.103 & $\begin{array}{c}1.92 \\
(0.056)\end{array}$ & 0.073 & $\begin{array}{c}1.330 \\
(0.186)\end{array}$ & -0.081 & $\begin{array}{c}-1.60 \\
(0.110)\end{array}$ & 0.065 & $\begin{array}{c}1.23 \\
(0.220)\end{array}$ & 0.030 & $\begin{array}{c}0.54 \\
(0.587)\end{array}$ \\
\hline _cons & 2.338 & $\begin{array}{c}20.47 \\
(0.000)\end{array}$ & 2.341 & $\begin{array}{c}20.42 \\
(0.000)\end{array}$ & 2.356 & $\begin{array}{c}20.48 \\
(0.000)\end{array}$ & 2.348 & $\begin{array}{l}20.370 \\
(0.000)\end{array}$ & 2.322 & $\begin{array}{c}20.35 \\
(0.000)\end{array}$ & 2.340 & $\begin{array}{c}20.41 \\
(0.000)\end{array}$ & 2.337 & $\begin{array}{c}20.20 \\
(0.000)\end{array}$ \\
\hline
\end{tabular}


Table 8: Regression Results of Criterion 2 (continued)

\begin{tabular}{|c|c|c|c|c|c|c|}
\hline & MODEL21 & MODEL 22 & MODEL 23 & MODEL 24 & MODEL 25 & MODEL 26 \\
\hline Num of obs & 824 & 824 & 824 & 824 & 824 & 824 \\
F( 10, 813) & 210.22 & 209.82 & 210.49 & 209.80 & 210.09 & 209.71 \\
Prob> F & 0.0000 & 0.0000 & 0.0000 & 0.0000 & 0.0000 & 0.0000 \\
R-squared & 0.7211 & 0.7207 & 0.7214 & 0.7207 & 0.7210 & 0.000 \\
Adj R-squared & 0.7177 & 0.7173 & 0.7179 & 0.7173 & 0.7176 & 0.7206 \\
\hline
\end{tabular}

p-value in parentheses

ISpec is calculated based on variables:

Model 21: Assets

Model 22: Sales

Model 23: Audit fees

Model 24: Total fees

Model 25: Number of clients

Model 26: Square root of assets

Model 27: Square root of sales 
Table 9 :Results of Ispec Coefficient Comparison

Panel A : ISpec Coefficients Comparison-Criterion 1

\begin{tabular}{|c|c|c|c|c|c|c|}
\hline & MODEL11 & MODEL12 & MODEL13 & MODEL14 & MODEL15 & MODEL16 \\
\hline MODEL12 & $\begin{array}{c}1.71 \\
(0.1915)\end{array}$ & & & & & \\
\hline MODEL13 & $\begin{array}{c}0.25 \\
(0.6164)\end{array}$ & $\begin{array}{c}0.10 \\
(0.7517)\end{array}$ & & & & \\
\hline MODEL14 & $\begin{array}{c}0.36 \\
(0.5505)\end{array}$ & $\begin{array}{c}0.05 \\
(0.8300)\end{array}$ & $\begin{array}{c}0.12 \\
(0.7321)\end{array}$ & & & \\
\hline MODEL15 & $\begin{array}{c}1.97 \\
(0.1600)\end{array}$ & $\begin{array}{c}6.39 \\
(0.0115)\end{array}$ & $\begin{array}{c}10.47 \\
(0.0012)\end{array}$ & $\begin{array}{c}10.58 \\
(0.0011)\end{array}$ & & \\
\hline MODEL16 & $\begin{array}{c}0.52 \\
(0.4724)\end{array}$ & $\begin{array}{c}2.15 \\
(0.1428)\end{array}$ & $\begin{array}{c}3.97 \\
(\mathbf{0 . 0 4 6 3})\end{array}$ & $\begin{array}{c}3.71 \\
(0.0541)\end{array}$ & $\begin{array}{c}1.71 \\
(0.1904)\end{array}$ & \\
\hline MODEL17 & $\begin{array}{c}0.09 \\
(0.7655)\end{array}$ & $\begin{array}{c}1.34 \\
(0.2463)\end{array}$ & $\begin{array}{c}1.77 \\
(0.1836)\end{array}$ & $\begin{array}{c}2.90 \\
(0.0888)\end{array}$ & $\begin{array}{c}3.31 \\
(0.0689)\end{array}$ & $\begin{array}{c}0.86 \\
(0.3530)\end{array}$ \\
\hline
\end{tabular}

Chi-square test, p-value in parentheses 
Panel B : ISpec Coefficients Comparison-Criterion 2

\begin{tabular}{|l|cccccc|}
\hline & MODEL21 & MODEL22 & MODEL23 & MODEL24 & MODEL25 & MODEL26 \\
\hline MODEL22 & 0.44 & & & & & \\
& $(0.5072)$ & & & & & \\
MODEL23 & 0.13 & 0.74 & & & & \\
& $(0.7198)$ & $(0.3886)$ & & & & \\
MODEL24 & 0.09 & 0.02 & 1.43 & & & \\
& $(0.7595)$ & $(0.9012)$ & $(0.2318)$ & & & \\
MODEL25 & $\mathbf{1 7 . 2 1}$ & $\mathbf{1 0 . 3 6}$ & $\mathbf{1 1 . 4 8}$ & $\mathbf{9 . 0 6}$ & & \\
& $(\mathbf{0 . 0 0 0 0}$ & $\mathbf{( 0 . 0 0 1 3 )}$ & $\mathbf{( 0 . 0 0 0 7 )}$ & $\mathbf{( 0 . 0 0 2 6}$ & & \\
MODEL26 & 1.45 & 0.01 & 0.78 & 0.03 & $\mathbf{1 4 . 4 6}$ & \\
& $(0.2283)$ & $(0.9311)$ & $(0.3767)$ & $(0.8624)$ & $\mathbf{( 0 . 0 0 0 1 )}$ & \\
MODEL27 & 1.38 & 0.95 & $\mathbf{5 . 4 1}$ & 1.99 & $\mathbf{4 . 0 7}$ & 0.54 \\
& $(0.2397)$ & $(0.3299)$ & $\mathbf{( 0 . 0 0 2 0}$ & $(0.1583)$ & $\mathbf{( 0 . 0 4 3 5 )}$ & $(0.4645)$ \\
\hline
\end{tabular}

Chi-square test, $\mathrm{p}$-value in parentheses 


\section{Appendix A:Variable Descriptions}

\begin{tabular}{|c|c|c|}
\hline Variable & Description & Calculation \\
\hline LnAUDFEE & Natural logarithm of audit fees & Natural logarithm of audit fees \\
\hline LnASSETS & Natural logarithm of assets & Natural logarithm of assets \\
\hline BIG4 & Whether a firm is audited by Big 4 auditors & Equals to 1 if a firm is audited by Big 4 auditors; 0 otherwise \\
\hline INVREC & Proportion of inventory and receivables relative to total assets & (inventory + receivables) $/$ total assets \\
\hline ROA & Return on Assets & net income / total assets \\
\hline LOSS & Whether a firm reported loss in year 2007 & Equals to 1 if net income is less than $0 ; 0$ otherwise \\
\hline MINING & Whether a firm is in the Metal and Coal Mining industry & $\begin{array}{l}\text { Equals to } 1 \text { if a firm belongs to Mining industry ( four-digit SIC code with } \\
\text { the beginning two-digit } 10 \text { and } 12 \text { ); } 0 \text { otherwise }\end{array}$ \\
\hline CROSSLIST & Whether a firm crosslists in US exchange & Equals to 1 if EXCHG variable in Compustat is larger than $10 ; 0$ otherwise \\
\hline wLEV & Leverage ratio, winsorized at $99 \%$ & Leverage ratio $=$ total liabilities $/$ total assets \\
\hline ISSUE & $\begin{array}{l}\text { Whether a firm issue new debt or equity that is more than } 5 \% \text { of the lag total } \\
\text { assets }\end{array}$ & $\begin{array}{l}\text { Equals to } 1 \text { if (change in long-term debt }+ \text { change in common equity) is } \\
\text { larger than } 5 \% \text { of the lag total assets; } 0 \text { otherwise }\end{array}$ \\
\hline ISpecij & 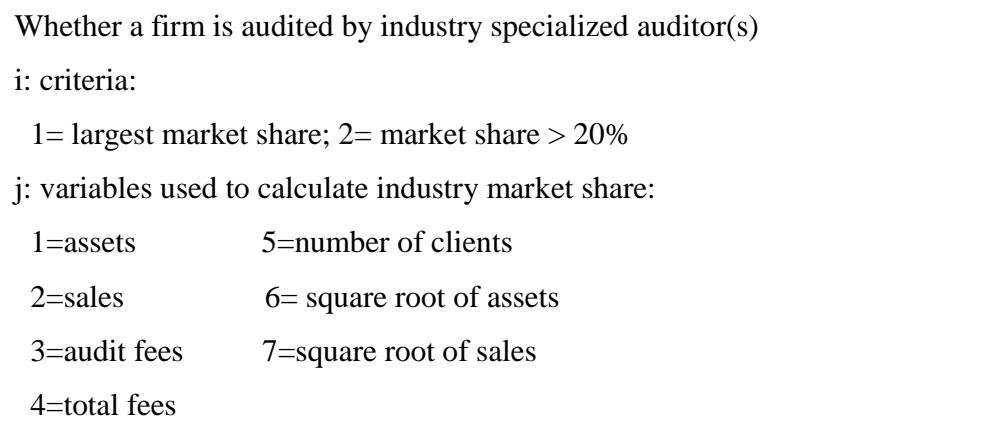 & Equals to 1 if a firm is audited by industry specialized auditor(s); 0 otherwise \\
\hline
\end{tabular}


Appendix B: Test of Multicollinearity

Panel A: Test of Multicollinearity: Regressions Model 11 to Model 17

\begin{tabular}{|c|c|c|c|c|c|c|c|c|c|c|c|c|c|c|}
\hline & \multicolumn{2}{|c|}{ Model 11} & \multicolumn{2}{|c|}{ Model 12} & \multicolumn{2}{|c|}{ Model 13} & \multicolumn{2}{|c|}{ Model 14} & \multicolumn{2}{|c|}{ Model 15} & \multicolumn{2}{|c|}{ Model 16} & \multicolumn{2}{|c|}{ Model 17} \\
\hline & VIF & R-Square & VIF & $\mathrm{R}$-square & VIF & R-square & VIF & R-square & VIF & $\mathrm{R}$-square & VIF & R-square & VIF & $\mathrm{R}$-square \\
\hline LnASSETS & 1.62 & 0.3816 & 1.60 & 0.3759 & 1.60 & 0.3753 & 1.60 & 0.3753 & 1.60 & 0.3752 & 1.60 & 0.3759 & 1.60 & 0.3758 \\
\hline BIG4 & 1.24 & 0.1910 & 1.25 & 0.2010 & 1.27 & 0.2129 & 1.27 & 0.2102 & 1.30 & 0.2294 & 1.27 & 0.2134 & 1.26 & 0.2092 \\
\hline INVREC & 1.38 & 0.2778 & 1.38 & 0.2774 & 1.38 & 0.2776 & 1.38 & 0.2774 & 1.39 & 0.2789 & 1.38 & 0.2774 & 1.38 & 0.2774 \\
\hline ROA & 1.54 & 0.3517 & 1.54 & 0.3517 & 1.54 & 0.3527 & 1.55 & 0.3528 & 1.55 & 0.3532 & 1.54 & 0.3514 & 1.54 & 0.3512 \\
\hline LOSS & 1.60 & 0.3741 & 1.60 & 0.3752 & 1.60 & 0.3766 & 1.60 & 0.3769 & 1.61 & 0.3777 & 1.60 & 0.3766 & 1.60 & 0.3745 \\
\hline MINING & 1.45 & 0.3106 & 1.45 & 0.3081 & 1.43 & 0.3002 & 1.43 & 0.3002 & 1.43 & 0.2990 & 1.42 & 0.2978 & 1.43 & 0.2997 \\
\hline CROSSLIST & 1.09 & 0.0791 & 1.09 & 0.0803 & 1.09 & 0.0790 & 1.09 & 0.0792 & 1.09 & 0.0790 & 1.09 & 0.0792 & 1.09 & 0.0800 \\
\hline wLEV & 1.47 & 0.3192 & 1.47 & 0.3191 & 1.47 & 0.3188 & 1.47 & 0.3188 & 1.47 & 0.3189 & 1.47 & 0.3190 & 1.47 & 0.3188 \\
\hline ISSUE & 1.17 & 0.1470 & 1.17 & 0.1473 & 1.17 & 0.1476 & 1.17 & 0.1477 & 1.17 & 0.1470 & 1.17 & 0.1469 & 1.17 & 0.1469 \\
\hline ISpec & 1.12 & 0.1081 & 1.11 & 0.0997 & 1.12 & 0.1068 & 1.12 & 0.1056 & 1.13 & 0.1156 & 1.12 & 0.1088 & 1.12 & 0.1034 \\
\hline Mean VIF & 1.37 & & 1.37 & & 1.37 & & 1.37 & & 1.37 & & 1.37 & & 1.37 & \\
\hline Max VIF & 1.62 & & 1.60 & & 1.60 & & 1.60 & & 1.60 & & 1.60 & & 1.60 & \\
\hline
\end{tabular}

Panel B: Test of Multicollinearity: Regressions Model 21 to Model 27

\begin{tabular}{|c|c|c|c|c|c|c|c|c|c|c|c|c|c|c|}
\hline & \multicolumn{2}{|c|}{ Model 21} & \multicolumn{2}{|c|}{ Model 22} & \multicolumn{2}{|c|}{ Model 23} & \multicolumn{2}{|c|}{ Model 24} & \multicolumn{2}{|c|}{ Model 25} & \multicolumn{2}{|c|}{ Model 26} & \multicolumn{2}{|c|}{ Model 27} \\
\hline & VIF & R-Square & VIF & $\mathrm{R}$-square & VIF & $\mathrm{R}$-square & VIF & R-square & VIF & $\mathrm{R}$-square & VIF & R-square & VIF & $\mathrm{R}$-square \\
\hline LnASSETS & 1.61 & 0.3793 & 1.61 & 0.3806 & 1.62 & 0.3819 & 1.62 & 0.3819 & 1.6 & 0.3746 & 1.61 & 0.3792 & 1.62 & 0.3826 \\
\hline BIG4 & 1.45 & 0.3087 & 1.4 & 0.2881 & 1.56 & 0.3589 & 1.62 & 0.3832 & 1.4 & 0.284 & 1.49 & 0.33 & 1.61 & 0.3798 \\
\hline INVREC & 1.39 & 0.2798 & 1.38 & 0.2774 & 1.39 & 0.2781 & 1.38 & 0.2774 & 1.39 & 0.2796 & 1.38 & 0.2779 & 1.38 & 0.2777 \\
\hline ROA & 1.54 & 0.3513 & 1.54 & 0.3517 & 1.54 & 0.3518 & 1.54 & 0.3515 & 1.54 & 0.3517 & 1.54 & 0.3519 & 1.54 & 0.3516 \\
\hline LOSS & 1.6 & 0.3762 & 1.6 & 0.3765 & 1.61 & 0.3785 & 1.61 & 0.3784 & 1.61 & 0.3772 & 1.61 & 0.3786 & 1.6 & 0.3754 \\
\hline MINING & 1.42 & 0.2969 & 1.42 & 0.2979 & 1.46 & 0.3161 & 1.45 & 0.3125 & 1.44 & 0.3065 & 1.42 & 0.297 & 1.48 & 0.3232 \\
\hline CROSSLIST & 1.09 & 0.0792 & 1.09 & 0.079 & 1.09 & 0.0802 & 1.09 & 0.0815 & 1.09 & 0.079 & 1.09 & 0.0794 & 1.09 & 0.0807 \\
\hline wLEV & 1.47 & 0.3196 & 1.47 & 0.3204 & 1.47 & 0.3197 & 1.47 & 0.3202 & 1.48 & 0.324 & 1.48 & 0.3236 & 1.48 & 0.3246 \\
\hline ISSUE & 1.17 & 0.147 & 1.17 & 0.147 & 1.17 & 0.1472 & 1.17 & 0.1473 & 1.17 & 0.1486 & 1.17 & 0.1484 & 1.17 & 0.147 \\
\hline ISpec & 1.34 & 0.2541 & 1.29 & 0.2228 & 1.46 & 0.3138 & 1.51 & 0.3382 & 1.29 & 0.2258 & 1.39 & 0.2817 & 1.52 & 0.3412 \\
\hline Mean VIF & 1.41 & & 1.40 & & 1.44 & & 1.45 & & 1.40 & & 1.42 & & 1.45 & \\
\hline Max VIF & 1.61 & & 1.61 & & 1.62 & & 1.62 & & 1.60 & & 1.61 & & 1.62 & \\
\hline
\end{tabular}

